\title{
Responses of Soil Microbial Activity to Swine Manure Applications
}

\author{
Maria Josiane Martinss ${ }^{1}$, Tânia Santos Silva ${ }^{2}$, Igor Paranhos Caldas ${ }^{1}$, Geovane Teixeira de Azevedo ${ }^{1}$, \\ Isabelle Carolyne Cardoso ${ }^{1}$, Daniela Ferreira Silveira ${ }^{1}$, Josiane Cantuária Figueiredo ${ }^{3}$, \\ Débora Souza Mendes ${ }^{4}$, Adelica Aparecida Xavier ${ }^{1}$, Michele Xavier Vieira Megda $^{1}$, \\ Regina Cássia Ferreira Ribeiro ${ }^{1} \&$ Nelson de Abreu Delvaux Júnior ${ }^{1}$ \\ ${ }^{1}$ Department of Agricultural Sciences, State University of Montes Claros, Janaúba, Minas Gerais, Brazil \\ ${ }^{2}$ University of Southwest Bahia, Vitória da Conquista, Bahia, Brazil \\ ${ }^{3}$ Federal University of Pelotas, Pelotas, Rio Grande do Sul, Brazil \\ ${ }^{4}$ State University of Northern Fluminense, Campos de Goytacazes, Rio de Janeiro, Brazil \\ Correspondence: Maria Josiane Martins, Department of Agricultural Sciences, State University of Montes Claros, \\ Janaúba, MG, Brazil. Tel: 55-389-8414-5313. E-mail: josianemartins102012@hotmail.com
}

Received: June 14, 2020

Accepted: July 20, 2020

Online Published: August 15, 2020

doi:10.5539/jas.v12n9p199

URL: https://doi.org/10.5539/jas.v12n9p199

\begin{abstract}
The Coordination for the Improvement of Higher Education Personnel (CAPES)-financing code 001, the National Council for Scientific and Technological Development (CNPq) and the Minas Gerais State Research Support Foundation (FAPEMIG) financed this work.
\end{abstract}

\begin{abstract}
The allocation of the large amount of swine waste from farms is an international concern. An efficient way of managing such waste is its use in farming. It is already known that the incorporation of organic waste into the soil significantly increases the microbial population. Therefore, the objective was to evaluate the impact of the use of swine manure on the soil microbiota in a Eutrophic Oxisol. The experiment was set up in a completely randomized design in a $6 \times 4$ factorial scheme (sixconcentrations of swine manure and four evaluation periods) with four replications. We evaluate the following characteristics: microbial respiration $\left(\mathrm{C}^{-} \mathrm{CO}_{2}\right)$, microbial biomass $\left(\mu \mathrm{C} \mathrm{g}^{-1}\right.$ soil) and $\mathrm{pH} .:$ microbial respiration $\left(\mathrm{C}^{-} \mathrm{CO}_{2}\right)$, microbial biomass $\left(\mu \mathrm{C} \mathrm{g}^{-1}\right.$ soil) and $\mathrm{pH}$. A significant effect was found in the interaction between concentrations and time of incubation $(p<0.05)$ of swine manure on microbial activity in the soil. The amount of microbial carbon increased as a function of increased levels of liquid swine manure. No interaction was observed between concentrations and time of incubation for the $\mathrm{pH}$. The evaluation of the isolated factors allowed to observe that the $\mathrm{pH}$ decreased as the doses of manure were incremented. Higher and lower $\mathrm{pH}$ values were found after 5 and 30 days of incubation. The application of liquid swine manure up to $6000 \mathrm{~L} \mathrm{ha}^{-1}$ increases the release of $\mathrm{CO}_{2}$ and carbon in the microbial biomass. The applications of liquid swine manure cause a gradual reduction in soil $\mathrm{pH}$.
\end{abstract}

Keywords: swine waste, microbiota, microbial biomass, microbial carbon

\section{Introduction}

The demand for animal husbandry is directly proportional to the growth of the world's population (Safavi \& Unnthorsson, 2017). The accelerated growth of swine rearing has caused an environmental issue due to the generation of large quantities of manure with high polluting potential (Veronese et al., 2019). To minimize this problem, one of the most rational forms of final disposal of these wastes is to use them as organic fertilizer (Miyazawa \& Barbosa, 2015) since they are rich in nutrients necessary for plant growth. The incorporation of these wastes improves the physical, chemical and biological qualities of the soil as the diet currently supplied to pigs is highly concentrated in elements that are not completely utilized by the metabolism of the animals, therefore causing the excretion of more chemically concentrated waste (Rosov et al., 2020).

The search for farming practices that result in high productivity, but that also consider the various aspects related to environmental quality is a complex equation whose resolution cannot neglect the biotic components of the soil (El-Ramady et al., 2014), which has a close interrelation with the physical and chemical components (Delgado \& Gomes, 2016). Thus, all factors that negatively affect microorganisms also cause the deterioration of the physical 
and chemical properties of the soil (Pereira et al., 2013). Among the parameters used to characterize the adequate microbiological functioning of the soil, the determination of microbial activity through basal respiration, microbial biomass and $\mathrm{pH}$ stand out (Novak et al., 2017).

The amount of $\mathrm{CO}_{2}$ released by the respiration of microorganisms is one of the most traditional and used methods in the assessment of the metabolic activity of the soil microbial population (Sabino et al., 2015). The estimation of microbial biomass can provide useful data on the changes that occur in the biological properties of soils, resulting from the types of the applied management (Semenov et al., 2018). Soils fertilized with organic waste tend to reduce the $\mathrm{pH}$, due to the characteristic processes of organic matter degradation, releasing ions into the medium, therefore, acidifying it (Carmo et al., 2016). Thus, the authors of this paper aimed at evaluating the impact of the use of swine manure on the soil microbial activity in a Eutrophic Oxisol.

\section{Material and Method}

The experiment was carried out in the Microbiology and Chemistry laboratories of the State University of Montes Claros. The samples of Eutrophic Oxisol were collected in the city of Jaíba, Minas Gerais (MG). The samples were sieved in a $2 \mathrm{~mm}$ mesh and maintained at $60 \%$ of the soil's total water retention capacity. The swine manure used in the experiment was collected from a biodigester in the Jaíba Project region, in the municipality of Jaíba-MG. This was digested anaerobically at $56^{\circ} \mathrm{C}$ for 30 days. The chemical composition of swine manure is described in table 1 . The experiment was conducted in a $6 \times 4$ factorial design, with six different concentrations of swine manure: $0,2000,3000,4000,5000$ and $6000 \mathrm{~L} \mathrm{ha}^{-1}$ and 4 evaluation periods $(5,10,20$ and 30 days), with four replications. Swine manure concentrations were determined according to the amount already applied to the soil by rural producers in the Jaíba region. It is thus adjusted, two concentrations upwards (5000 and $6000 \mathrm{~L} \mathrm{ha}^{-1}$ ) and two concentrations downwards (2000 and $3000 \mathrm{~L} \mathrm{ha}^{-1}$ ). The following characters were evaluated: microbial respiration $\left(\mathrm{C}-\mathrm{CO}_{2}\right)$, microbial biomass and $\mathrm{pH}$.

Table 1. Physicochemical composition of swine manure treated by anaerobic digestion $\left(56{ }^{\circ} \mathrm{C}\right.$ for 30 days)

\begin{tabular}{ll}
\hline Parameter & Values \\
\hline $\mathrm{pH}$ & $6.10 \pm 0.03$ \\
Turbidity (NTU-Nephelometric Turbidity Unit) & 345.00 \\
Total nitrogen $\left(\mathrm{mg} \mathrm{L}^{-1}\right)$ & $496.00 \pm 7.00$ \\
Total phosphorus $\left(\mathrm{mg} \mathrm{L}^{-1}\right)$ & $141.00 \pm 8.10$ \\
Total Carbon $\left(\mathrm{mg} \mathrm{L}^{-1}\right)$ & $2376.7 \pm 229.00$ \\
\hline
\end{tabular}

Note. Average of four repetitions, \pm standard deviation.

Five levels of manure were applied to each soil sample and homogenized using a glass stick. The soil microbial respiration was estimated by the amount of $\mathrm{CO}_{2}$ released from the soil during 5, 10, 20 and 30 days of incubation, according to the methodology proposed by Mendonça and Matos (2005). The $50 \mathrm{~g}$ samples of Eutrophic Oxisol were placed in plastic containers of $2 \mathrm{dm}^{3}$ at $28{ }^{\circ} \mathrm{C}$ and incubated aerobically in order to stimulate microbial activity. The moisture of the soil samples was adjusted to $60 \%$ of its total water retention capacity. The $\mathrm{CO}_{2}$ produced was captured by $30 \mathrm{~mL}$ of a $0.5 \mathrm{~mol} \mathrm{~L}-1 \mathrm{NaOH}$ solution and quantified by titration with $0.25 \mathrm{~mol} \mathrm{~L}^{-1}$ $\mathrm{HCl}, 10 \mathrm{~mL}$ of $0.05 \mathrm{~mol} \mathrm{~L}^{-1} \mathrm{BaCl}_{2}$ was previously added and phenolphthalein at $1 \%$ was used as an indicator. Four titrations were performed after the beginning of the samples incubation in which the first was performed at 5 days, the second at 10 days, the third at 20 days and the fourth at 30 days. The microbial respiration data were expressed in $\mathrm{mg} \mathrm{C}-\mathrm{CO}_{2} 100 \mathrm{~cm}^{-3}$ and calculated using the formula:

$$
\mathrm{C}-\mathrm{CO}_{2}(\mathrm{mg})=(\mathrm{B}-\mathrm{V}) \times \mathrm{M} \times 6 \times(\mathrm{V} 1 / \mathrm{V} 2)
$$

where, $\mathrm{B}=\mathrm{HCl}$ volume in the blank $(\mathrm{mL}) ; \mathrm{V}=$ Volume of $\mathrm{HCl}$ used in the sample $(\mathrm{mL}) ; \mathrm{M}=\mathrm{Real} \mathrm{HCl}$ concentration $\left(\mathrm{mol} \mathrm{L}^{-1}\right) ; 6=$ Carbon atomic mass (12) divided by the number of moles of $\mathrm{CO}_{2}$ that react with $\mathrm{NaOH}(2) ; \mathrm{V} 1=$ Total volume of $\mathrm{NaOH}$ used to capture $\mathrm{CO}_{2}(\mathrm{~mL}) ; \mathrm{V} 2=$ Volume of $\mathrm{NaOH}$ used in the titration $(\mathrm{mL})$.

The carbon in the microbial biomass was determined through irradiation-extraction according to the methodology proposed by Ferreira et al. (1999). Therefore, $40 \mathrm{~g}$ of soil were weighed in duplicates, one was irradiated in a microwave oven for 120 seconds to eliminate microorganisms and the other was not. After that, the duplicates were placed in $500 \mathrm{~mL}$ glass flasks for the carbon extraction process, with the addition of $50 \mathrm{~mL}$ of $0.5 \mathrm{~mol} \mathrm{~L}^{-1} \mathrm{~K}_{2} \mathrm{SO}_{4}$ to each flask. The set was kept under stirring at $220 \mathrm{rpm}$ for 30 minutes in a Tecnal-TE 
420-Incubator orbital shaker. After this period, the samples were filtered on filter paper. In $500 \mathrm{~mL}$ glass flasks, a $25 \mathrm{~mL}$ aliquot of the filtered extract and $10 \mathrm{~mL}$ of $\mathrm{K}_{2} \mathrm{Cr}_{2} \mathrm{O}_{7}$ extracting solution $0.167 \mathrm{~mol} \mathrm{~L}^{-1}$ and $20 \mathrm{~mL}$ of $\mathrm{H}_{2} \mathrm{SO}_{4} \mathrm{MW}$ were added. The set was then manually homogenized for one minute and allowed to cool for 30 minutes. Next, $200 \mathrm{~mL}$ of $\mathrm{H}_{2} \mathrm{O}$ and $10 \mathrm{~mL}$ of $\mathrm{H}_{3} \mathrm{PO}_{4} \mathrm{MW}$ were added. After, three drops of the Diphenylamine indicator were added, and the excess of Potassium Dichromate was titrated with $\mathrm{Fe}\left(\mathrm{NH}_{4}\right)_{2}\left(\mathrm{SO}_{4}\right)_{26} \mathrm{H}_{2} \mathrm{O} 0.4$ mol $\mathrm{L}^{-1}$. The microbial carbon values were expressed in $\mu \mathrm{g} \mathrm{g}^{-1}$ of soil and calculated using the formula:

$$
\text { Microbial carbon }\left(\mu \mathrm{g} \mathrm{g}^{-1} \mathrm{C} \text { in the soil }\right)=(\mathrm{IC}-\mathrm{NIC}) / \mathrm{Kc}
$$

where, $\mathrm{IC}=$ irradiated carbon sample; $\mathrm{NIC}=$ not-irradiated carbon sample; $\mathrm{Kc}=0.33$ (correction factor proposed by Sparling and West (1988).

The $\mathrm{pH}$ was determined according to the methodology described by Donagema et al. (2011) and performed in Tecnal ${ }^{\circledR}$ pH-meter. In $250 \mathrm{~mL}$ containers, 20 grams of soil and $25 \mathrm{~mL}$ of distilled water were placed. The containers were stirred at $220 \mathrm{rpm}$ for 30 minutes on a Tecnal-TE 420-Incubator ${ }^{\circledR}$ orbital shaker, then subjected to rest for 60 minutes. Soon after, the electrodes were soaked in the suspension solution and the $\mathrm{pH}$ was read. The $\mathrm{pH}$ analysis was performed after 5, 10,20 and 30 days of soil incubation. The data obtained in the evaluation of the experiment were subjected to tests of assumption of analysis of variance (Bartlett and Shapiro Wilk). The data were considered normal and were subjected to analysis of variance at $5 \%$ probability by the $t$ test When the interaction was significant $(\mathrm{p}<0.05)$, it unfolded. The swine manure concentrations were subjected to regression analysis at $5 \%$ probability by the $t$ test and the incubation days at the Tukey test at $5 \%$ probability. $R$ Core Team software version 3.5 (2015) was performed.

\section{Results}

A significant effect was observed on the interaction between concentrations and incubation time $(p<0.05)$ of swine manure on microbial activity in the soil. The unfolding of the interaction between the dose level and the incubation periods allowed to observe that at doses $0,2000,4000$ and $6000 \mathrm{~L} \mathrm{ha}^{-1}$, the highest values of basal respiration were observed on days 5,10 and 20 of incubation (Table 2). At the doses of 3000 and $5000 \mathrm{~L} \mathrm{ha}^{-1}$, the highest value of basal respiration was found at 10 days of incubation. Regardless of the dose used, the lowest basal respiration values were found at 30 days of incubation (Table2). All variables of the regressions in the four evaluation periods were significant at $5 \%$ probability by the T-test. The determination of the microbial activity of the soil by basal respiration allowed verifying the effect of the application of different concentrations of swine manure in four incubation periods (Figure 1).

Table 2. Basal respiration ( $\mathrm{mg} \mathrm{C}-\mathrm{CO}_{2} / 100 \mathrm{~cm}^{3}$ ) of Eutrophic Oxisol as a function of the incubation days and the applied doses of swine manure

\begin{tabular}{|c|c|c|c|c|c|c|}
\hline \multirow{2}{*}{ Incubation days } & \multicolumn{6}{|c|}{ Swine manure concentrations $\left(\mathrm{L} \mathrm{ha}^{-1}\right)$} \\
\hline & 0 & 2000 & 3000 & 4000 & 5000 & 6000 \\
\hline 5 & $102.23 \mathrm{a}$ & $107.21 \mathrm{ab}$ & $111.15 b$ & $114.75 \mathrm{a}$ & $116.77 b$ & $120.26 \mathrm{a}$ \\
\hline 10 & $100.29 \mathrm{a}$ & $108.79 \mathrm{a}$ & $114.8 \mathrm{a}$ & $116.44 \mathrm{a}$ & $120.49 a$ & $121.50 \mathrm{a}$ \\
\hline 20 & $98.21 \mathrm{a}$ & $104.96 \mathrm{~b}$ & $110.36 b$ & $114.07 \mathrm{a}$ & $116.55 b$ & $120.15 \mathrm{a}$ \\
\hline 30 & $93.71 b$ & $97.31 \mathrm{c}$ & $100.23 \mathrm{c}$ & $106.76 b$ & $109.12 \mathrm{c}$ & $111.71 \mathrm{~b}$ \\
\hline Coefficient of variation $(\%)$ & 1.69 & & & & & \\
\hline
\end{tabular}

Note. Means followed by the same letter in the column do not differ by Tukey's test at $5 \%$ probability. 


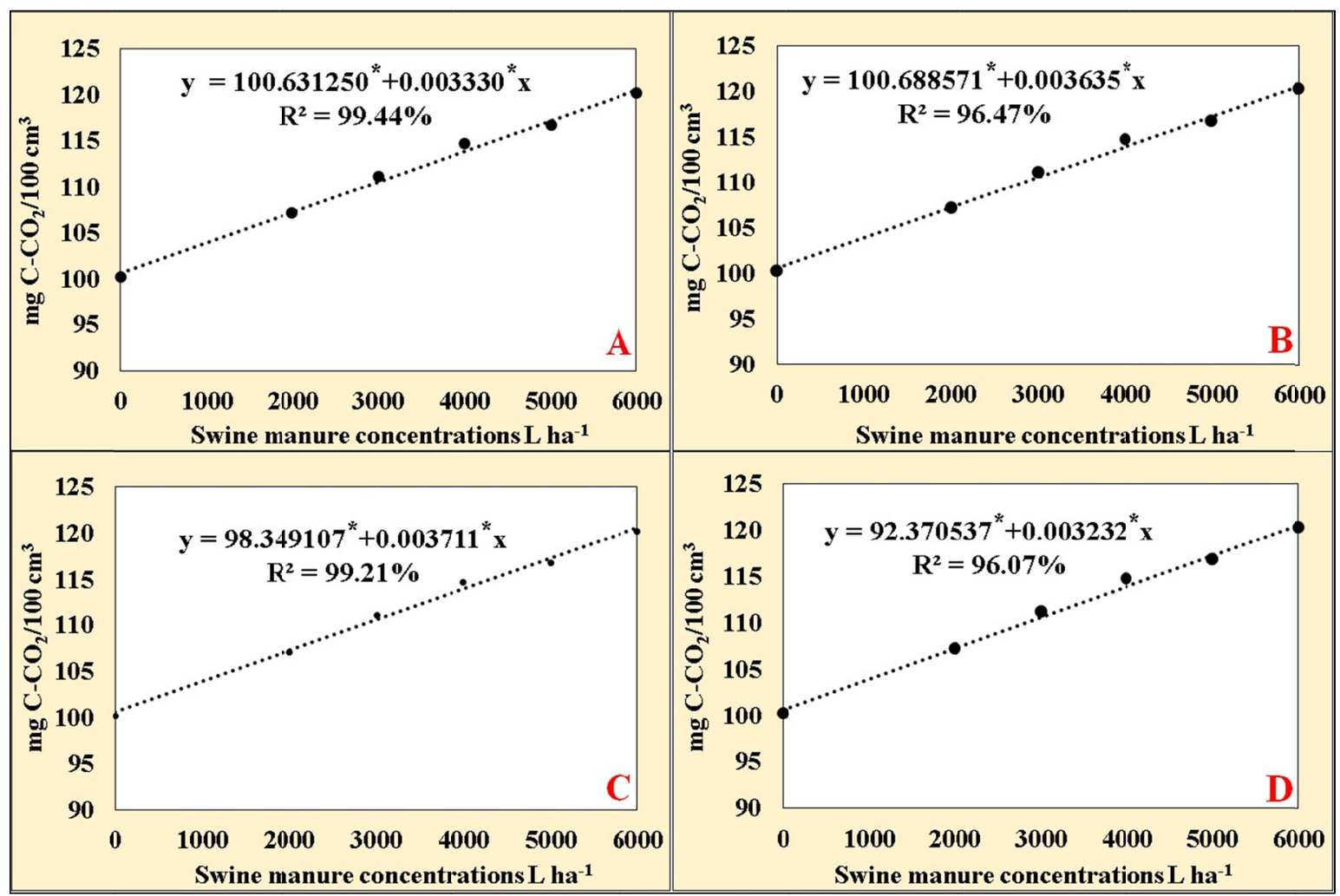

Figure 1. $\mathrm{C}-\mathrm{CO}_{2}$ release according to the concentrations applied and the evaluation periods. * Significant at $5 \%$ probability by the $t$ test. Incubation periods 5 (A), 10 (B), 20 (C) and 30 (D) days

The unfolding of the interaction between incubation periods within each dose level shows that at dose 0 , regardless of the incubation period, the carbon of the microbial biomass remained the same (Table 3). Higher microbial carbon values were found at 20 days of incubation at the concentrations 2000, 3000, 4000, 5000 and $6000 \mathrm{~L} \mathrm{ha}^{-1}$ (Table 2), indicating greater metabolic activity in this period.

Table 3. Microbial carbon ( $\mu \mathrm{C} \mathrm{g}^{-1}$ soil) of Eutrophic Oxisol as a function of the incubation days and the applied concentrations of swine manure

\begin{tabular}{lllllll}
\hline \multirow{2}{*}{ Incubation days } & \multicolumn{5}{c}{ Swine manure concentrations $\left(\mathrm{L} \mathrm{ha}^{-1}\right)$} \\
\cline { 2 - 6 } & 0 & 2000 & 3000 & 4000 & 5000 & 6000 \\
\hline 5 & $122.57 \mathrm{a}$ & $163.12 \mathrm{~b}$ & $187.05 \mathrm{~b}$ & $270.25 \mathrm{~b}$ & $273.60 \mathrm{bc}$ & $283.60 \mathrm{~b}$ \\
10 & $138.439 \mathrm{a}$ & $169.22 \mathrm{~b}$ & $180.87 \mathrm{~b}$ & $207.95 \mathrm{~b}$ & $285.21 \mathrm{~b}$ & $308.90 \mathrm{~b}$ \\
20 & $119.82 \mathrm{a}$ & $448.80 \mathrm{a}$ & $445.52 \mathrm{a}$ & $482.12 \mathrm{a}$ & $477.50 \mathrm{a}$ & $484.07 \mathrm{a}$ \\
30 & $101.82 \mathrm{a}$ & $158.12 \mathrm{~b}$ & $152.50 \mathrm{~b}$ & $223.92 \mathrm{~b}$ & $230.47 \mathrm{c}$ & $322.07 \mathrm{~b}$ \\
\hline Coefficient of variation (\%) & 11.07 & & & & & \\
\hline
\end{tabular}

Note. Means followed by the same letter in the column do not differ by Tukey's test at 5\% probability.

The interaction between concentrations and incubation days was significant for the variable response, the carbon in the microbial biomass $(\mathrm{p}<0.05)$. The unfolding of the interaction between the dose within each level of the evaluation period allowed to observe a linear behavior for days 5 and 10 (Figure 2) and a quadratic behavior for days 20 and 30 (Figure 2). The regression parameters on days 5, 10, 20 were all significant at $5 \%$ probability by the $t$ test $t(p<0.05)$. Only the parameter $\beta 1$ of the regression equation on day 30 was not significant $(p>0.05)$. The derivation of the equations for the days 20 and 30 generated a maximum and a minimum point of 4,346.71 $\mathrm{L}$ $\mathrm{ha}^{-1}$ and $990.25 \mathrm{~L} \mathrm{ha}^{-1}$, respectively. 


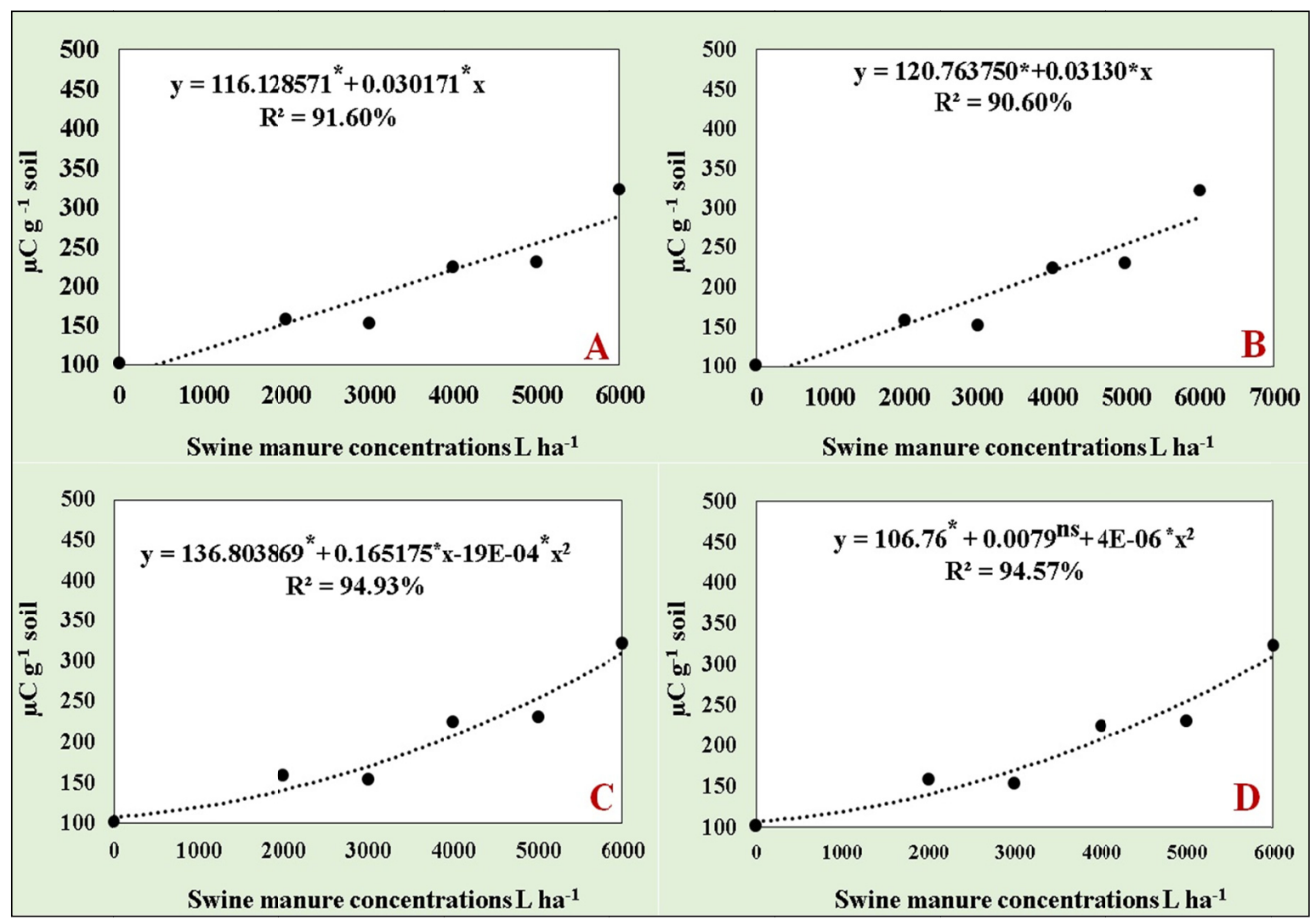

Figure 2. Microbial carbon $\left(\mu \mathrm{C} \mathrm{g}^{-1}\right.$ soil) as a function of the concentrations applied and the evaluation periods.* significant and ${ }^{\text {ns }}$ not-significant at $5 \%$ probability by the $\mathrm{T}$ test.

Incubation periods 5 (A), 10 (B), 20 (C) and 30 (D) days

No significant interaction was observed between the applied concentrations and the days of incubation $(\mathrm{p}>0.05)$. The evaluation of the isolated factors showed that the $\mathrm{pH}$ decreased as the concentrations increased (Figure 3A). The lowest $\mathrm{pH}$ value was found at $6000 \mathrm{~L} \mathrm{ha}^{-1}$. The highest and lowest $\mathrm{pH}$ values were observed at 5 and 30 days of incubation (Figure 3B).

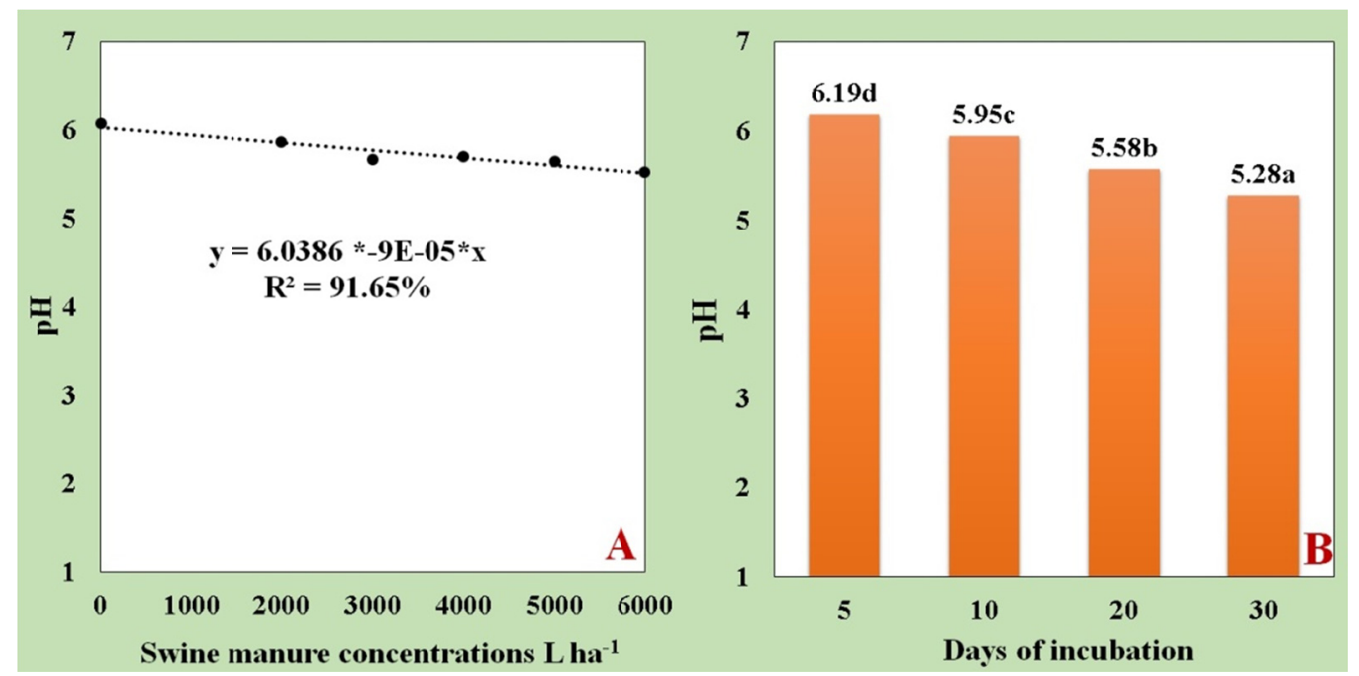

Figure 3. Hydrogen potential $(\mathrm{pH})$ as a function of the different concentrations of swine manure. Means followed by the same letter in the bar do not differ by Tukey's test at $5 \%$ probability. Coefficient of variation $2.64 \%$ 


\section{Discussion}

The residues organic in the soil activate physiological responses of microorganisms, which are shown on the performance of the microbial community (Grenni et al., 2018). These physiological effects can be assessed using variables such as basal respiration and microbial biomass, since they display the metabolic processes involved in the growth and reproduction of these organisms (Anderson \& Domsch, 2010). The increase in the concentration of swine manure resulted in the rise for $\mathrm{CO}_{2}$ (Figure 1). The linear model equations show an increase for $\mathrm{CO}_{2}$ due to the increase in the levels of liquid swine manure. In all concentrations of swine manure, the $\mathrm{C}-\mathrm{CO}_{2}$ values were higher than in the control treatment. The increase in theamount of mineralizable carbon is explained by the increase and availability of organic matter in the soil, which improves the environment for the development of microbial flora (Quadro et al., 2011).

Basal respiration is an indicator of soil quality and the available organic carbon for heterotrophic microorganisms. In addition, the greater the amount of $\mathrm{CO}_{2}$ released per unit of soil weight, the greater the amount of assimilable substrate for the growth of microbial biomass (Oliveira et al., 2016). The concentration of residue organic applied to the soil influences the amount of nutrients and mainly of the organic carbon available to the soil microbiota. Silva et al. (2015) found that the concentration of $200 \mathrm{~m}^{3} \mathrm{ha}^{-1}$ swine liquid manure applied to the soil resulted in higher microbial respiration values.

According to Morales et al., (2016), the high values of basal respiration point to a greater metabolic activity of microorganisms as the $\mathrm{CO}_{2}$ flow correlates with the intensity of the catabolic processes. Aerobic decomposition of organic residues occurs in biochemical redox reactions (Hullebusch et al., 2019) through which the microorganisms obtain energy using part of the carbon in the substrate in catabolic reactions while $\mathrm{CO}_{2}$ is released (Podmirseg et al., 2019). The evolution of $\mathrm{CO}_{2}$ as a measure of respiration, then, represents a measure of total decomposition (Londoño, 2012).

Firstly, microbial biomass degrades the substrates recently added to the soil, or part of them (Ali et al., 2018). In addition, after that, the metabolic activity and consumption of the remaining substrates increases (Bonner et al., 2018). In the final stage, the substrate reaches a status similar to the initial one of the soils, and there is a decline in microbial activity and biomass (Cortes-Tolalpa et al., 2018), therefore, reducing basal respiration, which was observed in this study at 30 days of incubation.

There was an increase in carbon due to the increase in swine liquid manure concentrations in the evaluated period. Microbial biomass is the total mass of microorganisms in a particular volume of soil or even the living component of the organic matter according to Miltner et al. (2012). Biomass is responsible for a large part of the biological activity of the soil, this is the main source of enzymes responsible for the biochemical transformations that occur there (Singh et al., 2014).

Balota et al. (2012) when working with the concentrations of 0, 30, 60 and $120 \mathrm{~m}^{3} \mathrm{ha}^{-1}$, also saw significant increases for biomass as the volume of swine manure applied to the soil increased. Studies evaluating microbial biomass in soils fertilized with swine manure have shown increases in the carbon content of microbial biomass in relation to soils without fertilization (Morales et al., 2016). These changes occur through the addition of microorganisms by means of manure, which contribute to the increase in carbon in microbial biomass ( $\mathrm{Li}$ et al., 2018). Moreover, the addition of low molecular-weight compounds and easy transport across the cell membrane increases the number of resources available or partially utilized by the microorganisms, which can increase in quantity due to the favorable condition that the manure creates temporarily (Londoño, 2012).

Microbial biomass has the ability to mineralize and to immobilize nutrients. In addition, the characterization of microbial communities, as well as their cycles, can be useful for understanding and explaining changes of these organisms, of the nutrient cycling and decomposition and mineralization processes (Cardoso et al., 2013). Microbial biomass be as the central compartment in the carbon cycle, where it is associated with the processes of decomposition of plant residues until the cycling of the constituents of the organic matter (Cronan, 2018).

Currently, an immense range of organic compounds it is used to support the demand for nutrients by crops such as sewage sludge, sludge from tanneries, oil residues, animal waste, among others (Zhang et al., 2017). Because microbial biomass uses such organic wastes as a source of nutrients, it directly affected when applied to the soil (Teutscherova et al., 2017). Tavares et al. (2019) when working with swine manure $\left(25,50,100\right.$ and $\left.200 \mathrm{~m}^{3} \mathrm{ha}^{-1}\right)$ application in cerrado soils in Brazil, concluded that the application of this residue promoted the mineralization of organic matter, resulting in the formation of humic substances and improvement in the degree of soil structure.

The fluctuation of soil $\mathrm{pH}$ caused by the metabolic activity of microorganisms is dependent on the type of the substrate metabolized. The addition of carbohydrate reduces the initial $\mathrm{pH}$ by producing acidic and $\mathrm{CO}_{2}$ 
metabolites (Song et al., 2018). The application of nitrogen fertilizers has an acidic residual effect caused by the nitrification reaction. The decomposition of organic matter can decrease the $\mathrm{pH}$ of the soil due to the formation of organic acids in the first stage of the decomposition of the anaerobic phase (Santos et al., 2015), which justifies the $\mathrm{pH} 6.08$ at concentration 0 and more acid in other concentrations $(2000,3000,4000,5000$ and 6000 $\left.L \mathrm{ha}^{-1}\right)$.

The soil microbial components have been being the indicators of the dynamics of organic matter due to their rapid turnover (Cagnarini et al., 2019). In this context, the parameters evaluated in this experiment showed microbial activity, when these are offered a lesser or greater amount of nutrients. As well as the period in which this source of nutrients is available in the soil, affecting its dynamics.

\section{Conclusion}

The application of liquid swine manure up to the dose of $6000 \mathrm{~L} \mathrm{ha}^{-1}$ increases the release of $\mathrm{CO}_{2}$ and the carbon in the microbial biomass at days 5, 10,20 and 30 of incubation. The applications of liquid swine manure cause a gradual reduction in soil $\mathrm{pH}$.

\section{Acknowledgments}

This publication is a production of research projects financed by the Coordination for the Improvement of Higher Education Personnel (CAPES) - financing code 001, National Council for Scientific and Technological Development (CNPq) and the Research Support Foundation of the State of Minas Gerais (FAPEMIG). Maria Josiane Martins, Tânia Santos Silva, Igor Paranhos Caldas, Geovane Teixeira de Azevedo, Adelica Aparecida Xavier and Michele Xavier Vieira Megda designed the experiment. Igor Paranhos Caldas supplied the swine manure used in the experiment. Maria Josiane Martins, Tânia Santos Silva, Isabelle Carolyne Cardoso, Daniela Ferreira Silveira, Josiane Cantuária Figueiredo, Débora Souza Mendes with the help of Adelica Aparecida Xavier conducted the experiment. Maria Josiane Martins, Josiane Cantuária Figueiredo and Débora Souza Mendes performed the statistical analysis of the data. Maria Josiane Martins, Adelica Aparecida Xavier and Michele Xavier Vieira Megda discussed the results. Adelica Aparecida Xavier, Michele Xavier Vieira Megda, Regina Cássia Ferreira Ribeiro and Nelson de Abreu Delvaux Júnior coordinated and merged the individual contributions of the authors. All authors read, revised and approved the submitted aversion.

\section{References}

Ali, S. R., Poll, C., \& Kandeler, E. (2018). Dynamics of soil respiration and microbial communities: Interactive controls of temperature and substrate quality. Soil Biology and Biochemistry, 127, 60-70. https://doi.org/ 10.1016/j.soilbio.2018.09.010

Anderson, T. H., \& Domsch, K. H. (2010). Soil microbial biomass: The ecophysiological approach. Soil Biology and Biochemistry, 42, 2039-2043. https://doi.org/10.1016/j.soilbio.2010.06.026

Balota, E. L., Machinesk, O., \& Matos, M. A. (2012). Soil microbial biomass under different tillage and levels of applied pig slurry. Revista Brasileira de Engenharia Agrícola e Ambiental, 16, 487-495. https://doi.org/ $10.1590 /$ S1415-43662012000500004

Bonner, M. T. L., Shoo, L. P., Brackin, R., \& Shimidta, S. (2018). Relationship between microbial composition and substrate use efficiency in a tropical soil. Geoderma, 315, 96-103. https://doi.org/10.1016/j.geoderma. 2017.11.026

Cagnarini, C., Blyth, E., Emmett, B. A., Evans, C. D., Griffths, R. I., Keith, A., ... Cosby, B. J. (2019). Zones of influence for soil organic matter dynamics: A conceptual framework for data and models. Glob Change Biology, 25, 3996-4007. https://doi.org/10.1111/gcb.14787

Cardoso, E. J. B. N., Vasconcellos, R. L. F., Bini, D., Miyauchi, Y. M., Santos, C. A., Alves, P. R. L., ... Nogueira, M. A. (2013). Soil health: Looking for suitable indicators. What should be considered to assess the effects of use and management on soil health? Scientia Agricola, 70, 274-289. https://doi.org/10.1590/ S0103-90162013000400009

Carmo, D. L., Lima, L. B., \& Silva, C. A. (2016). Soil fertility and electrical conductivity affected by organic waste rates and nutrient inputs. Revista Brasileira de Ciência do Solo, 40, e0150152. https://doi.org/ $10.1590 / 18069657 \mathrm{rbcs} 20150152$

Cortes-Tolalpa, L., Norder, J., Elsas, J. D. V., \& Salles, J. F. (2018). Halotolerant microbial consortia able to degrade highly recalcitrant plant biomass substrate. Applied Microbiology and Biotechnology, 102, 2913-2927. https://doi.org/10.1007/s00253-017-8714-6 
Cronan, C. S. (2018). Cycling of organic matter. In C. S. Cronan (Eds.), Ecosystem Biogeochemistry. Springer Textbooks in Earth Sciences, Geography and Environment. Cham, SWI: Springer. https://doi.org/ 10.1007/978-3-319-66444-6

Delgado, A., \& Gomes, J. A. (2016). The soil. Physical, chemical and biological. In F. J. Villalobos \& E. Fereres (Eds.), Principles of Agronomy for Sustainable Agriculture. Cham, SWI: Springer. https://doi.org/ 10.1007/978-3-319-46116-8_2

Donagema, G. K., Campos, D. V. V., Calderano, S. B., Teixeira, W. G., \& Viana, J. H. M. (2011). Manual de métodos de análise de solos. Rio de Janeiro: RJ: Embrapa Solos.

El-Ramady, H. R., Alshaal, T. A., Amer, M., Domoko-Szabolcsy, E., EL-Hawat, N., Prokisch, J., \& Fari, M. (2014). Soil quality and plant nutrition. In H. Ozier-Lafontaine \& M. Lesueur-Jannoyer (Eds.), Sustainable Agriculture Reviews. Cham, SWI: Springer. https://doi.org/10.1007/978-3-319-06016-3

Ferreira, A. S., Camargo, F. A. O., \& Vidor, C. (1999). Utilização de micro-ondas na avaliação da biomassa microbiana do solo. Revista Brasileira de Ciência do Solo, 23, 991-996. https://doi.org/10.1590/ S0100-06831999000400026

Grenni, P., Ancona, V., \& Caracciolo, A. B. (2018). Ecological effects of antibiotics on natural ecosystems: A review. Microchemical Journal, 136, 25-39. https://doi.org/10.1016/j.microc.2017.02.006

Hullebusch, E. D. V., Yekta, S. S., Calli, B., \& Fermoso, F. G. (2019). Biogeochemistry of major elements in anaerobic digesters: Carbon, nitrogen, phosphorus, sulfur and iron. In F. G. Fermoso, E. D. V. Hullebusch, G. Collins, J. Roussel, A. P. Mucha, \& G. Esposito (Eds.), Trace elements in anaerobic biotechnologies. Lodon, UK: IWA Publishing. https://doi.org/10.2166/9781789060225

Li, J., Wu, X., Gebremikael, M. T., Wu, H., Cai, D., Wang, B., ... Xi, Y. (2018). Response of soil organic carbon fractions, microbial community composition and carbon mineralization to high-input fertilizer practices under an intensive agricultural system. PLoS ONE, 13, e0195144. https://doi.org/10.1371/journal.pone. 0195144

Londoño, D. M. M. (2012). Respostas da comunidade microbiana do solo a sucessivas aplicações de uréia e dejetos suínos em solo sob plantio direto (Unpublished Master's Thesis, Federal University of Santa Catarina, Florianópolis, Brazil).

Mendonça, A. L. P., \& Matos, C. A. M. (2005). Matéria orgânica do solo. Viçosa, MG: UFV.

Miltner, A., Bombach, P., \& Schmidt-Brücken, B. (2012). SOM genesis: Microbial biomass as a significant source. Biogeochemistry, 111, 41-55. https://doi.org/10.1007/s10533-011-9658-z

Miyazawa, M., \& Barbosa, G. M. C. (2015). Dejeto líquido de suíno como fertilizante orgânico: Método simplificado. Londrina, PR: IAPAR.

Morales, D., Vargas, M. M., Oliveira, M. P., Taffer, B. L., Comin, J., Soares, C. R., \& Lovato, P. (2016). Response of soil microbiota to nine-year application of swine manure and urea. Ciência Rural, 46, 260-266. https://doi.org/10.1590/0103-8478cr20140565

Novak, E., Carvalho, L. A., Santiago, F., \& Portilho, I. I. (2017). Chemical and microbiological attributes under diferent soil cover. CERNE, 23, 19-30. https://doi.org/10.1590/01047760201723012228

Oliveira, W. R. D., Ramos, M. M. G., Carvalho, A. M., Coser, T. R., Silva, A. M. M., Lacerda, M. M., ... Pulrolnik, K. (2016). Dynamics of soil microbiological attributes under integrated production systems, continuous pasture, and native cerrado. Pesquisa Agropecuária Brasileira, 51, 1501-1510. https://doi.org/ $10.5433 / 2316-5200$

Pereira, J. M., Baretta, D., Bini, D., Vasconcellos, R. L. F., \& Cardoso, E. J. B. B. (2013). Relationships between microbial activity and soil physical and chemical properties in native and reforested Araucaria angustifolia forests in the state of São Paulo, Brazil. Revista Brasileira de Ciência do Solo, 37, 572-586. https://doi.org/10.1590/S0100-06832013000300003

Podmirseg, S. M., Waldhuber, S., Knapp, B. A., Insam, H., \& Goberna, M. (2019). Robustness of the autochthonous microbial soil community after amendment of cattle manure or its digestate. Biology and Fertility of Soils, 55, 565-576. https://doi.org/10.1007/s00374-019-01371-w

Quadro, M. S., Castilhos, D. D., Castilhos, R. M. V., \& Vivian, G. (2011). Biomassa e atividade microbiana em solo acrescido de dejeto suíno. Revista Brasileira de Agrociência, 17, 85-93. https://doi.org/10.18539/ CAST.V17I1.2035 
R Core Team. (2015). R: A language and environment for statistical computing. R Foundation for Statistical Computing, Vienna, Austria.

Rosov, K. A., Mallina, M. A., \& Cahood, B. (2020). Waste nutrients from U.S. animal feeding operations: Regulations are inconsistent across states and inadequately assess nutrient export risk. Journal of Environmental Management, 269, 110738. https://doi.org/10.1016/j.jenvman.2020.110738

Sabino, P. H. S., Moino, Jr. A., Vanessa, A., Lima, L. M. Z., \& Sales, F. S. (2015). A method for measuring the concentration of $\mathrm{CO}_{2}$ released by entomopathogenic nematodes. Revista Colombiana de Entomología, 41, 280-282.

Safavi, S. M., \& Unnthorsson, R. (2017). Enhanced methane production from pig slurry with pulsed electric field pre-treatment. Environmental Technology, 39, 479-489. https://doi.org/10.1080/09593330.2017.1304455

Santos, S. R., Kondo, M. K., Oliveira, P. M., Andrade Junior, I. O., \& Matos, A. T. (2015). Short-term changes in soil properties due to sanitary wastewater irrigation used as a potassium source. Australian Journal Crop Science, 8, 713-720.:https://doi.org/10.1590/1809-4430

Semenov, M., Blagodatskaya, E., Stepanov, A., \& Kuzyakov, Y. (2018). DNA-based determination of soil microbial biomass in alkaline and carbonaceous soils of semi-arid climate. Journal of Arid Environments, 150, 54-61. https://doi.org/10.1016/j.jaridenv.2017.11.013

Silva, D. M., Antonniolli, Z. I., Jacques, R. J. S., Silveira, A. O., Silva, D. A., Rache, M. M., ... Silva, B. R. (2015). Indicadores microbiológicos de solo em pastagem com aplicação sucessiva de dejetos suínos. Revista Brasileira de Ciência do Solo, 39, 1585-1594. https://doi.org/10.1590/01000683rbcs20150138

Singh, M. K., \& Ghoshald, N. (2014). Variation in soil microbial biomass in the dry tropics: impact of land-use change. Soil Research, 52, 299-306. https://doi.org/10.1071/SR13265

Song, C., Li, M., Qia, H., Zhang, Y., Liu, D., Xi, X., ... Xi, B. (2018). Impact of anti-acidification microbial consortium on carbohydrate metabolism of key microbes during food waste composting. Bioresource Technology, 259, 1-9. https://doi.org/10.1016/j.biortech.2018.03.022

Sparling, G. P., \& West, A. W. (1988). A direct extraction method to estimate soil microbial C: Calibration in situ using microbial respiration and ${ }^{14} \mathrm{C}$ labeled sells. Soil Biology Biochemistry, 20, 337-343. https://doi.org/ 10.1016/0038-0717

Tavares, R. L. M., Assis, R. L., Ferreira, R. V., Menezes, J. F. S., Simon, G. A., Boldrin, P. F., \& Cantão, V. C. G. (2019). Long term application of pig manure on the chemical and physical properties of Brazilian Cerrado soil. Journal Carbon Management, 10, 541-549. https://doi.org/10.1080/17583004.2019.1676095

Teutscherova, N., Vazquez, E., Santana, D., Navas, M., Massaguer, A., \& Benito, M. (2017). Influence of pruning waste compost maturity and biochar on carbon dynamics in acid soil: Incubation study. European Journal of Soil Biology, 78, 66-74. https://doi.org/10.1016/j.ejsobi.2016.12.001

Veronese, M. L., Schwantes, D., Gonçalves, A. C., Richard, A., Mafrin, J., Schiller, A. P., \& Schuba, B. Production of biogas and biofertilizer using anaerobic reactors with swine manure and glycerin concentrations. Journal of Cleaner Production, 213, 176-184. https://doi.org/10.1016/j.jclepro.2018.12.181

Zhang, X., Wang, X. Q., \& Wang, D. F. (2017). Immobilization of Heavy Metals in Sewage Sludge during Land Application Process in China: A Review. Sustainability, 9, 2-19. https://doi.org/10.3390/su9112020

\section{Copyrights}

Copyright for this article is retained by the author(s), with first publication rights granted to the journal.

This is an open-access article distributed under the terms and conditions of the Creative Commons Attribution license (http://creativecommons.org/licenses/by/4.0/). 